$\mathrm{Oz}$

$1-1-2018$

\title{
Li Hui: From a Nightclub to Eternity
}

Phil Zheng Cai

Follow this and additional works at: https://newprairiepress.org/oz

Part of the Architecture Commons

(c) (1) $\Theta \Theta$

This work is licensed under a Creative Commons Attribution-Noncommercial-No Derivative Works 4.0 License.

\section{Recommended Citation}

Zheng Cai, Phil (2018) "Li Hui: From a Nightclub to Eternity," Oz: Vol. 40. https://doi.org/10.4148/

2378-5853.1582

This Article is brought to you for free and open access by New Prairie Press. It has been accepted for inclusion in Oz by an authorized administrator of New Prairie Press. For more information, please contact cads@k-state.edu. 


\section{Li Hui}

\section{From a Nightclub to Eternity}

\section{Phil Zheng Cai}

Application and maneuver of light sources is commonly associated with interior design, stage production, or architecture, but rarely as a motor or prime resource for fine art creation in a dominating fashion. Hui's fascination with laser light started with a random encounter in a nightclub. He saw a single beam of green laser and was stunned by it. To Li, it was the most rational and calm thing that touches the eternity. Since then, Hui has been experimenting and practicing art with laser and many other elements including mirror and smoke.

The connection between authenticity and Hui's work can be traced to his understanding of fine art creation in relation to religions. He is not religious and he believes the ability to create is exclusively anthropic. He argues that artists are playing more of a role to replace God in what they create, they invent, and influence. This is the pinnacle of authenticity. However when it comes to fear of the unknown, fear of the dark, and fear of the mysterious, as often demonstrated in his works, it is never authentic since these properties have inhabited people's mind and body for thousands of years.

Sir Jerome Sans, director of the Ullens Center for Contemporary
Art in Beijing, referred to Li Hui as an "archaeologist of the future." On appearance, Hui's choice of medium might seem incredibly modern, his manifestation western, yet Chinese philosophy has a strong influence in his creation. An old Chinese aphorism claims, "Using bronze as a mirror enables you to dress appropriately. Using history as a mirror enables a dynasty to measure its prosperity. Using man as a mirror reflects what you gain and what you loose." To me, when what being reflected is eternity as in Hui's work "V," all three of the above are achieved.
Images: Klein Sun Gallery ( L Li Hui

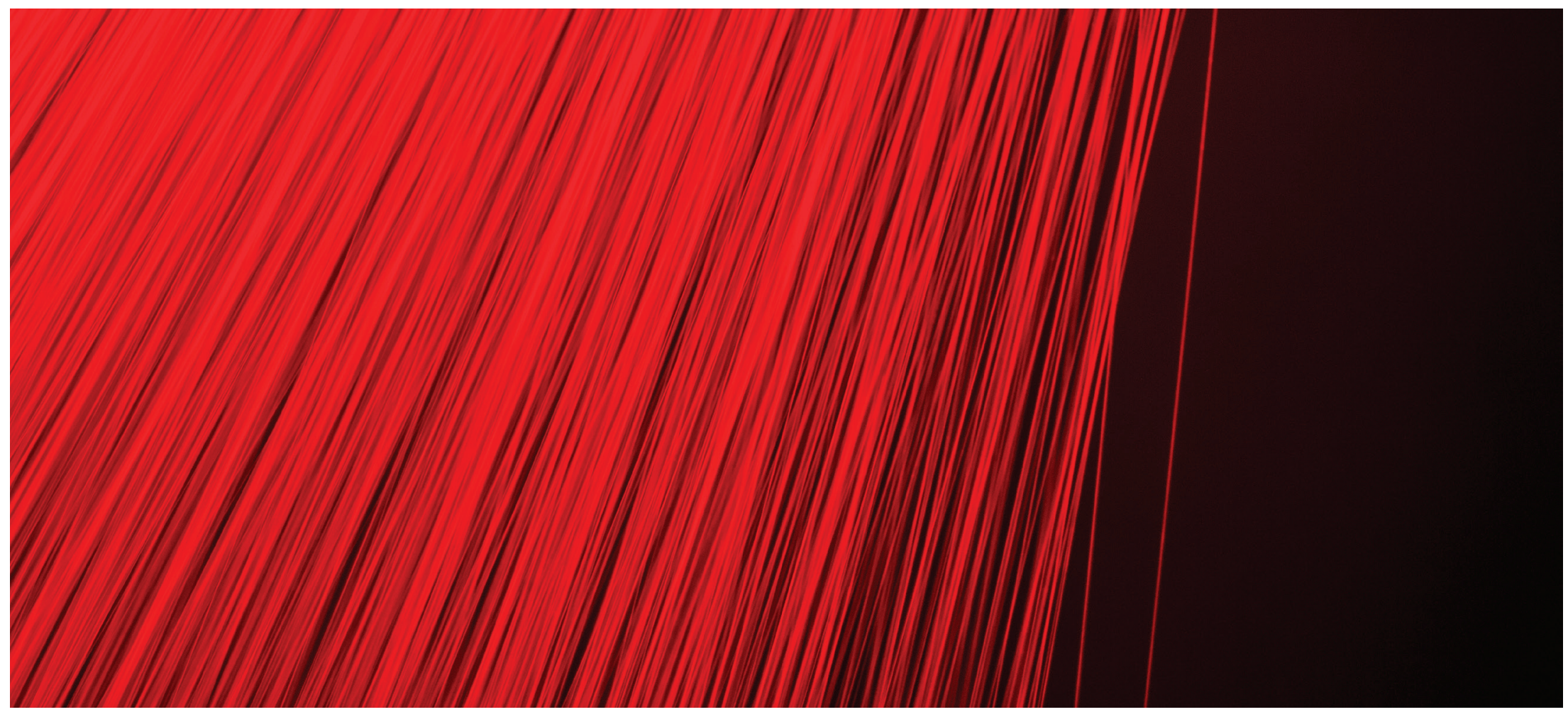




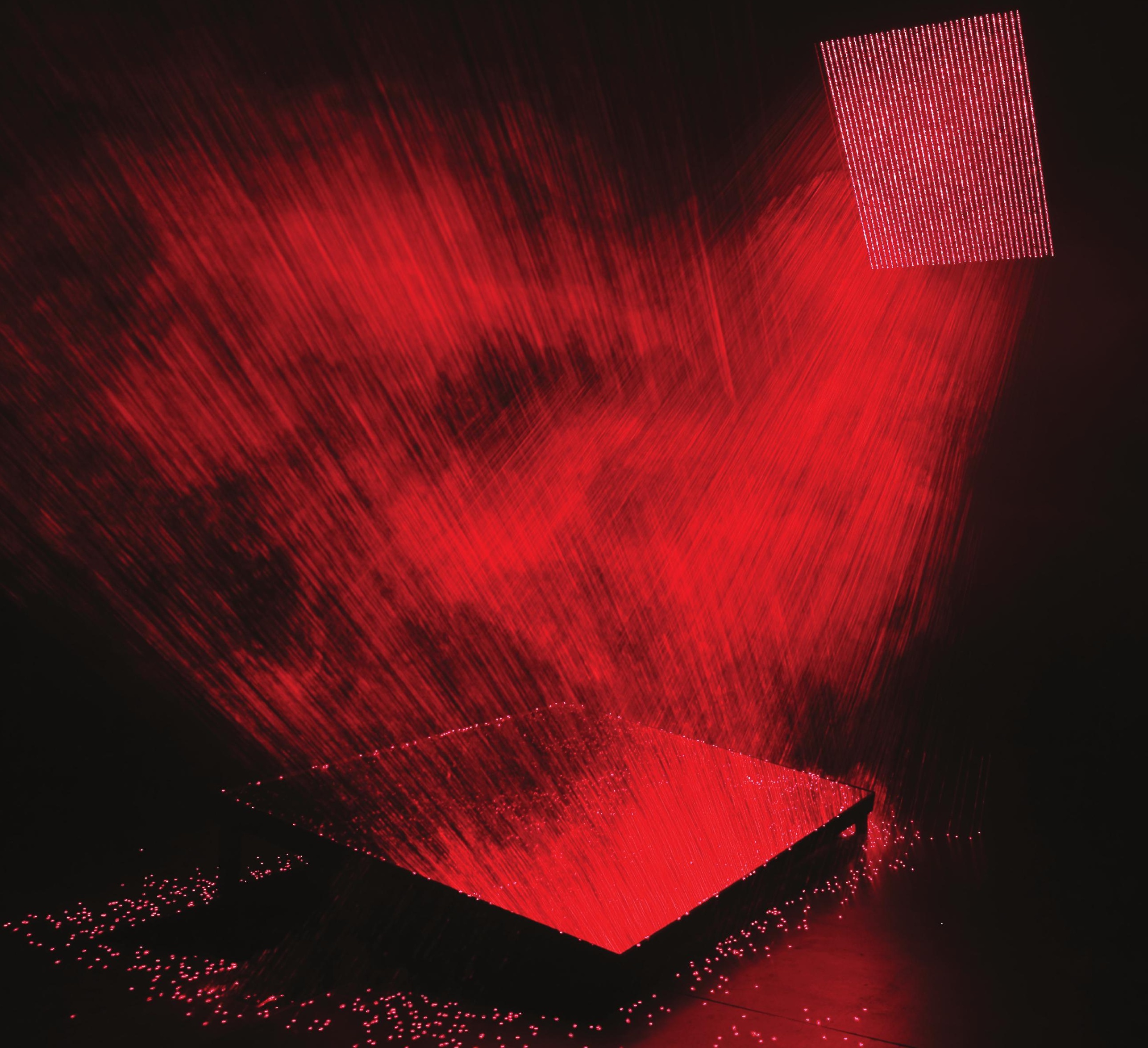

